\title{
The use of the term 'DNA' as a missiological metaphor in contemporary Church narratives
}

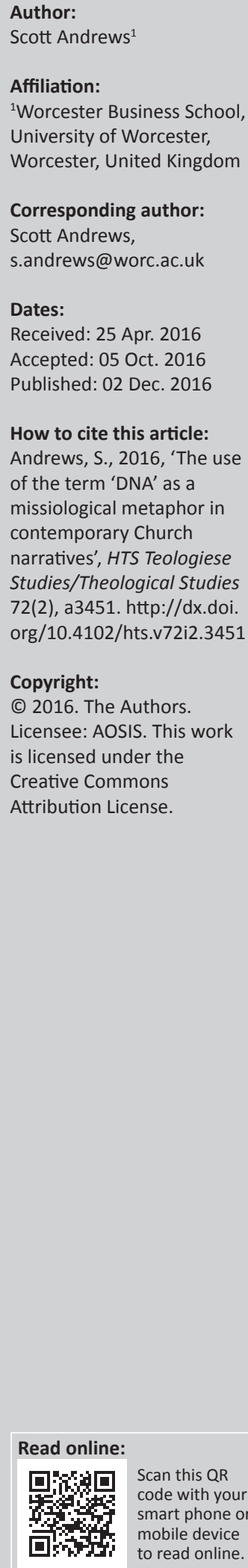

\begin{abstract}
Missiologists propose that the Church and mission are inseparable as the Church has its very being because there is mission, and it is the Missio Dei which constitutes the Church. In recent history the Anglican Church has interpreted this as the essential 'DNA' of the local church which is to be a missional community. The church's mission therefore is presented as the gift of participating through the Holy Spirit in the Son's mission from the Father to the world. In other words, it is proposed that the Church is both the fruit of God's mission and the agent of His mission. But, in order to communicate this relationship between Church and mission in a postmodern context, the use of new metaphors and new terminologies, which are derived from our contemporary context, is shaping new ways of thinking. An exploration of the development of missional churches considers the significance of developing and embedding what has become referred to as missional DNA or $m D N A$ at every level of the organisation of the Church. This $m D N A$ is the outward model of missional behaviour that compels the whole church to reach a lost world. It can be seen from evidence-based, case study research amongst large churches in the UK that there is consistency in the adoption and use of the term DNA by its leadership in reference to the local church's values and its attitude towards mission. This article explores the hypothesis that the term DNA is commonly accepted amongst local churches as a contributor to a contemporary language that forms the narrative of the Church and explores its feasibility and shortcomings as an adopted missiological metaphor.
\end{abstract}

\section{Introduction}

The 20th century was a period of significant advancement in the understanding of human genetics. By 1944 Avery, MacLeod and McCarty had established that deoxyribonucleic acid (or DNA) is the genetic material of biological cells, which had formerly been referred to as the chemical transforming principle (Purves et al. 2004:215). It was noted that it is through DNA that cell transformation takes place. The double helix structure of DNA deduced by Watson and Crick determines its function (Reiss \& Straughan 1996:13-25). It led to the proposal that DNA can assume a variety of different structural forms (Berg, Tymoczko \& Stryer 1995:746), and from this discovery two practical scientific applications were discovered: the polymerase chain reaction, which enables the production of multiple copies of DNA; and DNA sequencing which led to genetic coding and the birth of what is now referred to as genomics (Purves et al. 2004:231).

Since these developments, the use of these genetic terms has been adopted as metaphors across a range of disciplines, and the biological meaning of the terms has been stretched and adapted to form a new contemporary narrative. For example, in 1999 the Harvard Business Review (HBR) published an article entitled 'De-coding the DNA of the Toyota Production System' providing a critical analysis of the manufacturer's distinctive modes of production, which was considered a major contributor to the company's outstanding business performance (Spear \& Bowmen 1999). Similarly, the use of DNA as a metaphor was adopted in an HBR publication in 2009 that explored 'The Innovator's DNA' - a review of how an understanding about the ability to innovate provides what the authors described as the 'secret sauce' of business success (Dyer, Gregersen \& Christensen 2009). This narrative form was also adopted by Dobni in an article published in the Journal of Business Strategy to describe the characteristics of a successful business approach to innovation (Dobni 2008).

The use of DNA as a metaphor has been examined in the context of organisational studies. The phrase Organisational DNA was reported in the Ivey Business Journal as a term which can be changed or modified in organisational contexts to provide a distinct advantage when the behaviour of certain managers, for example, throws programmes or goals off the rails. The authors assert that: 
We use the DNA metaphor because it is useful in understanding the idiosyncratic characteristics of an organisation. Like the DNA of living organisms, the DNA of living organisations consists of four essential building blocks which combine and recombine to express distinct identities or personalities. (Knott \& Neilson 2006:2)

They point out that in keeping with its biological roots, Organisational DNA also has building blocks, which can be manipulated and modified. So this raises the question to what degree is it appropriate for biological metaphors that have already been adopted and accepted in organisational studies to be incorporated in narratives relating to the local church?

Helen Cameron (2004) asserts that there are four major challenges (or as she refers to them 'barriers') when translating management theory and concepts whilst undertaking organisational studies with church congregations:

1. Organisational studies involve a complex multidisciplinary approach incorporating a diversity of academic approaches.

2. There is an ideological assumption that if a company is well managed then it is likely to achieve its mission and resolve social issues, but this ignores the Spiritual dimension to church life, growth and development.

3. There is an assumption that, as all organisations are bureaucratic, then lessons learnt can be easily transferred from one to another, but this ignores the fact that churches differ widely in terms of their levels and layers of bureaucratic structures.

4. Given the rational and utilitarian assumptions that pervade organisational studies they may sit at odds with the mindset of congregations and church leaders, which might argue that the criteria are at best inappropriate or worse still offensive to God.

In spite of these suggestions, Eddie Gibbs and Ian Coffey (2010) point out that a growing number of churches in the UK are receiving leadership training and are drawing guidance from the teaching of the business sectors and from management literature into which emerges the use of DNA as a potentially church-oriented metaphor. It is perhaps therefore not surprising that the use of such biological terminologies such as DNA, genetic engineering and decoding have become adapted and utilised as descriptive metaphors amongst church leaders, practitioners and commentators. Whilst the term is widely understood to represent a metaphor for a building block or an organic structure, its interpretation has expanded to become more widely adopted as a descriptor related to values, identity, behaviour, vision and process (Andrews 2014).

Whilst this article does not examine issues of DNA in relation to culture, humanity, race and ethnicity, it does raise the question of whether or not it is feasible to draw on such metaphors in the context of the local church and mission? Are the adaptation and adoption of biological metaphors consistent with biblical thinking? And if so, then in what ways should the use of the term be appraised and moderated in order to ensure clarity of understanding and wherever possible agreement and approval on its use between practitioners and the academy? And perhaps most importantly, what is its significance to a contemporary understanding of applied theology and, in particular, when applied to current thinking about missiology?

\section{Current uses of the DNA terminologies as metaphors in church practice}

Friedrich de Wet examines the use of the term in the context of prophecy. He reflects on theological markers and argues for what he refers to as:

a pneumatology in which the work of the Spirit consists of grafting the very DNA of our humanity and all its faculties into Christ, the only One who can open up the true life that is intended for humanity by divine grace. (De Wet 2014:1)

He explores the relationship between human and divine action, the process of regeneration and more specifically using DNA and genetic engineering as metaphors in the role of prophetic speech in divine regeneration.

In a recent case study-based investigation of leadership teams from eight large, growing churches in the UK, the use of the term DNA was a consistent metaphor which was volunteered by almost all respondents in interviews without the prompting of the interviewer (Andrews 2014). In most cases there was broad agreement that the metaphor was used interchangeably with the term values and was adopted into the narrative of each church's vision and values statements.

Megan E. Gesler (2013:45) explores the use of the term DNA as a metaphor in her studies on Identity and Identification in Church Leadership. Her case-based research examines the use of a contemporary narrative in leadership teams of a start-up, local church organisation, and she notes that the leadership employs the term DNA as part of what she refers to as the 'negotiating process' between the church leaders and the wider congregation. She noted that the respondent interviewees proffered the use of the term without any prompting from the interviewer, stating that it was both a live and ideographic metaphor which formed a prominent part of the leadership narrative in relation to the manner by which the church communicated its beliefs and ideas, and how these were translated into actions. The term DNA was perceived to be related to both an appreciation of current behaviours and the church's heritage. For example, one leader stated:

DNA is that intangible thing that creates a people to make decisions to move a church forward, where it's not something you talk about every day, it's in everything you do. (Gesler 2013:45)

Whilst DNA is recognised as a double helix in its biological construction, from a practical standpoint Gesler asserts that 
the church's so-called DNA is a double hermeneutic for the organisation insofar as it refers to a principle that is understood as its own concept, but that understanding is used to further explain the principle. In a recursive fashion, DNA determines behaviour and that behaviour in turn indicates the presence and type of DNA found in the individual. To this end, it is reasonable to argue that there are some consistent similarities with the term's usage in biology and in its use in developing a contemporary understanding of church behaviour. The author concludes that a clearly defined DNA provides a means for communicating the values and beliefs of the local church in its specific context.

\section{The use of biological terms as missiological metaphors}

Bosch (1991:519) argues that the Church and mission are inseparable and that the Church has its very being because there is mission, and it is the Missio Dei which constitutes the church. The Archbishop's Council which produced the report entitled Mission Shaped Church (MSC) interprets this as the essential DNA of the local church which is to be a missional community. The MSC report proposes that the church's mission is described as the gift of participating through the Holy Spirit in the Son's mission from the Father to the world; or as Dearborn (1998) explains: 'It is not the church of God that has a mission in the world, but the God of mission that has a church in the world'. In other words, it is proposed that the church is therefore both the fruit of God's mission and the agent of His mission (Torrance 1996:ix).

George Lings produced an article entitled: 'Unravelling the DNA of Church: How Can We Know that What is Emerging is "Church"?' within which he examines the assertions of the MSC report. Lings (2006:106-107) notes that use of the DNA of Church terminology addresses three distinct theological concerns:

1. To isolate the essence of 'Church'

2. To retain the fullness of 'Church'

3. To understand the mechanism of starting a Church.

Whilst he acknowledges the tensions that such language might create for theologians, attention is drawn to the significant capacity that such a language brings to the local church when attempting to communicate in meaningful contemporary terms with, what the MSC report (2004:11, 25, 39) describes as, a post-denominational, unchurched, postmodern culture. Whilst advocating the benefits of such a language he does caution that it must have the capacity to demonstrate continuity with the past (Lings 2006:106). On the latter of the three points, Lings reflects on the significance of the DNA metaphor as a contributor to the narrative for church planting. Whilst DNA is central to the biochemical mechanism that enables living things to reproduce and evolve, he argues that such terminologies invite an exploration of how the church reproduces and evolves to enable new expressions of church to form.
This theme is also picked up in the MSC report (2004):

Planting is a process, but unless and until the kingdom and the mission are in the DNA of the seed of the church, what is planted will prove to be sterile. (p. 33)

In this context the MSC report recognised the use of the DNA metaphor as representing a core aspect of what it later refers to as the identity of church, and from this perspective the report proposed a broad range of different expressions of church.

However, it could be counter-argued that identity, values and beliefs should be consistent with the One True Church concept as outlined in the Nicene Creed rather than different expressions of church (Church of England 1662). This argument is examined by Roland Riem who, in his article published in Ecclesiology, asserts that the use of the metaphor DNA undermines the arguments established by the Anglican Church for MSCs. In particular, he raises concerns about how the focus on values that correspond to the use of the term $D N A$ creates a tension that challenges the so-called health of the church. He critiques the use of DNA to describe what he refers to as a 'cluster of abstract attributes which can be pressed into any form or other' preferring to draw attention to the use of the term to represent a consistent building block. Nonetheless, in spite of his anxieties on the notion of missional churches, he acknowledges that there is a place for an appropriate usage of the metaphor.

Whilst on the one hand there might be an argument in favour of consistency and uniformity in church practice in support of the notion of the One True Church, far from demonstrating a single model for church ministry and leadership, Derek Tidball proposes that there are 14 different models of church leadership and/or ministry in the New Testament. Just as Griffiths noted in the 1920s that it is through the DNA that cell transformation takes place to enable DNA to assume a variety of structural forms, Tidball examines the concept of unity in diversity - a perspective which may be referred to as many models one gospel (Tidball 2008:235). He asserts that the New Testament offers a high level of flexibility in the way that church leadership, mission and ministry are exercised such that 'it would be foolish to replace this responsiveness with rigidity' (Tidball 2008:243). These models are not all complementary and there are some legitimate links and some that are unlinked; 'they are neither mutually exclusive nor in conflict with each other'. The complementary nature of these models mean that they are not in competition nor is one model better than another, but each model is context specific. This is very relevant when comparing biblical approaches to church mission and ministry, and is consistent with the biological metaphor of DNA structuring and sequencing.

In his book Decoding the Church: Mapping the DNA of Christ's $B o d y$, Howard Snyder draws attention to what he refers to as the primary biblical image of the nature of the church: that of the body of Christ; to which he asserts that the classical understanding of the church as defined by the Nicene 
Creed - one, holy, catholic, apostolic church - comprises only one strand of the church's DNA. He proposes a more complex, living model for the structuring of the church and for understanding its mission. Just as DNA transforms the cell, he explores how a biblically structured church can transform the world (Snyder \& Runyon 2011).

He examines Pauline assertions proposing that the body is not simply a simile for the church and neither is the church just like a body. The church does not merely resemble a body in its diversity, unity and interdependence, but rather it is the body of Christ, who is its head. Snyder seeks to join the DNA metaphor to Paul's body metaphor as a way of saying that the reality of the church's relation to Christ is deeper and more complex than we might think.

DNA is, as Watson and Crick announced in 1953, a double helix. Snyder asks whether our churches have been operating with only half their DNA. He takes the creed's four classic marks of the church - one, holy, universal and apostolic - and asks whether there is not a second scriptural strand that intertwines those attributes from which he draws attributes of diversity, charismatically gifted, locally contextualised and prophetic. Snyder proposes that the first strand of DNA tends towards the institutional and hierarchical, whilst diverse, gifted, contextualised and prophetic are good reminders of the organic (body-like) nature of the church, and are essential in order that the church might be equipped for mission.

\section{Church DNA or missional DNA?}

Perhaps the real challenge is to determine where to draw the line in terms of the usage of such metaphors. For example, in an article by Craig Van Gelder the so-called 'emerging DNA of a missional movement' is explored as a part of a critique of the missional Church and church denominations. The author, drawing on a range of themes, begins with the premise that the church is created and called to be missional and asserts that the 'theological DNA of the missional church movement is Trinitarian' and that these Trinitarian virtues are referred to as the 'DNA of a missiological understanding of the Trinity' (Gelder 2008:167). He continues to validate his justification for these assertions on the grounds that 'ancient Methods of Hybridization, such as grafting, are biblical images. Genetic mapping and genetic engineering are 21st century processes that elicit ethical questions and emotional responses'. He advocates the usage of the language of DNA as a metaphor for what he describes as the level, kinds and processes of change that are involved in becoming a missional church. However, is there a danger that such broad applications of DNA terminologies may lead to confusion amongst practitioners and contemporary theologians? And would a more boundaried usage of the metaphor be more appropriate?

Roxburgh and Romanuk (2006:XV) agree that there has been confusion between the language of mission and that which refers to church growth, church health and church effectiveness. The interchangeable use of these terms and the accompanied use of church DNA can be misleading and/or lead to a misinterpretation of the term mission. Such shortcomings are observed by Stetzer (2006) who also raises concern over the language of mission. He identifies what he refers to as the 'missional perspective' of church as being the number one constant of growing churches and argues that the 'missional behaviour' of the whole church community, as opposed to the leader being 'missionminded', is a key factor for adaptability and sustained growth. He refers to being missional as the process of 'doing mission right where you are' (Stetzer 2006:19), whereas being mission-minded is more about an attitude of 'caring about mission'. As such he refers to a missional church as being 'on mission' or 'being intentional and deliberate about reaching others'. To be on mission also requires a focus not just on the church's mission but also on God's mission (missio Dei) 'being aware of what God is doing in the culture and joining him in his work' (Stetzer 2006:20). So is it to this notion of being on mission that the usage of DNA terminology might best be applied?

Alan Hirsh develops this thinking further in his proposal for a practical guide for developing missional churches, from which he explores the significance of developing and embedding what he refers to as missional DNA or mDNA (Hirsch 2006:11) at every level of the organisation of the church. He argues that from $100 \mathrm{AD}$ to $310 \mathrm{AD}$, when Constantine established the church in Rome, the number of Christians rose from as few as 25000 to as many as 20000000 . He theorises that it is reasonable to assume that this growth was the result of a massive missional investment, the likes of which he asserts is needed once again to counter the current decline in church attendance. ${ }^{1}$ He argues that this could only have been made possible (against a backdrop of negative cultural forces and persecution of that time) through the embedded $m D N A$ exhibited at every member level. This $m D N A$ is the outward model of missional behaviour that compels the whole church to reach a lost world as opposed to the inward model of attractional church that 'hinders the power of multiplication'. He asserts that this 'Missional-Incarnational Impulse' is one of the church's 'Forgotten Ways' (Hirsch 2006:12). This results in the development of what Gibbs and Coffey had formerly referred to as 'incarnational communities' that shift from being 'inviting churches to infiltrating churches' that are 'prepared to live adventurously with diversity and paradox' and ultimately for the whole church - leadership and congregants - to adapt to a new and consistently changing 21st century postmodern paradigm (Gibbs and Coffey 2001:211).

\section{Conclusion}

This article recognises that there is widespread adoption of the term DNA in contemporary church narratives, which provides evidence in support of its feasibility, whilst recognising that there are also shortcomings in some of the ways in which its use is interpreted. There is evidence to

1.This assertion is an assumption given what Hirsch describes as limited historical data, but draws on the proposals for early church growth submitted by Rodney Stark in his book the Rise of Christianity, 1996. 
support the view that the Church is seeking to develop new contributions to the language of theology to aid effective communication (Dreyer 2015; The Archbishops' Council 2004). In the 20th century it was discovered that through DNA cell transformation takes place. Similarly, there is evidence today that church practitioners support the view that a clear communication of the church's vision and values through the use of DNA as a transformational metaphor contributes to a language through which the church can effectively communicate, particularly in its missional context. The discovery of the polymerase chain reaction enables the production of multiple copies of DNA, and since the publication of MSC, the use of DNA metaphors has been applied to multiple fresh expressions of church, endorsed by senior members of the Anglican Church and adopted by many church practitioners.

It is therefore reasonable to conclude that whilst there are shortcomings in the use of DNA and other biological terms as metaphors for church behaviour, values, structure and attitudes which do not meet with universal acceptance, it is recognised that they have been adapted and adopted in a variety of forms by church practitioners, leaders and commentators, and they have provided a means by which the local church can orientate itself, more specifically around a missional agenda. In this regard, it is feasible to conclude that the use of the term, as a metaphor, has provided support to the understanding of the relationship between the Church and mission. In his appraisal of the Church and its capacity to understand its nature and calling in a 21st century postmodern context, Dreyer (2015:5) asserts that 'the creation and use of a new vocabulary is an essential tool'. This view is widely held by contemporary scholars, in support of the search for a new language in theology (Gelder 2008; Hirsch 2006; Lings 2006; Roxburgh \& Romanuk 2006). Thus, in practice, it would appear that such terminologies have become widely accepted as helpful contributors to a dialogue about the relationship between the contemporary church and mission. In this regard, such terms appear to have been well accepted for the generalisations they provide as a missiological metaphor in contemporary church narratives. However, there are shortcomings where the use of such terms, which have their origins in biological sciences, is subject to over-interpretation to justify specific actions or activities in church narratives. Excessive over-interpretation may bring such metaphors into sharper scrutiny for the confusing interpretations they might provide. The widespread usage of the DNA metaphor provides further scope for explorations of its viability as a component of a contemporary narrative for the Church and mission studies.

\section{Acknowledgements Competing interests}

The author declares that he has no financial or personal relationships which may have inappropriately influenced him in writing this article.

\section{References}

Andrews, S.M., 2014, 'A critical and theological examination of attitudes and behaviours towards mission, leadership and organisational structures in large growing churches in the UK', PhD thesis, University of Bristol, UK.

Berg, J.M., Tymoczko, J.L. \& Stryer, L., 1995, Biochemistry, 5th edn., W.H. Freeman \& Co., New York, NY.

Bosch, D.J., 1991, Transforming mission, Orbis, New York.

Cameron, H., 2004, 'Are congregations associations? The contribution of organisation studies to congregational studies', in M. Guest, K. Tusting, \& L. Woodhead (eds.), Congregational studies in the UK - Christianity in a post-Christian context, pp. 139-152, Ashgate Publishing, Ashgate.

Church of England, 1662, The book of common prayer, Oxford University Press, Oxford.

Dearborn, T, 1998, Beyond duty: A passion for Christ, a heart for mission, MARC Publishers, Seattle, WA.

De Wet, F.W., 2014, 'The DNA of prophetic speech', HTS Theological Studies 72(2), 1-8. http://dx.doi.org/10.4102/hts.v70i2.2052

Dobni, C.B., 2008, 'The DNA of innovation', Journal of Business Strategy 29(2), 43-50. http://dx.doi.org/10.1108/02756660810858143

Dreyer, W., 2015, 'The real crisis of the church', HTS Teologiese Studies/Theological Studies 71, 1-5. http://dx.doi.org/10.4102/hts.v71i3.2822

Dyer, J.H., Gregersen, H.B. \& Christensen, C.M., 2009, 'The innovator's DNA', Harvard Business Review 87(12), 60-67.

Gelder, C.V., 2008, The missional church and denominations: Helping congregations develop a missional identity, Wm. B. Eerdmans Publishing Co, Grand Rapids, MI.

Gesler, M.E., 2013, "You is the church": Identity and identification in church leadership', PhD thesis, The University of Montana, Missoula, MT.

Gibbs, E. \& Coffey, I., 2001, Church next - Quantum changes in Christian ministry, InterVarsity Press, Nottingham.

Hirsch, A., 2006, The forgotten ways, Brazos Press, Grand Rapids, MI.

Knott, D.G. \& Neilson, G.L., 2006, 'Organizing to execute: It's in the DNA', Ivey Business Review, Dec 2009, pp. 1-7.

Lings, G., 2006, 'Unravelling the DNA of church: How can we know that what is emerging is church?', Journal for the Study of the Christian Church 6(1), 104-116. http://dx.doi.org/10.1080/14742250500508028

Purves, W.K., Sadava, D., Orians, G.H. \& Heller, H.C., 2004, Life: The science of biology, 7th edn., Sinauer Assoc Inc., Sunderland, MA.

Reiss, M.J. \& Straughan, R., 1996, Improving nature? The science and ethics of genetic engineering, University Press, Cambridge, pp. 13-25.

Roxburgh, A.J. \& Romanuk, F., 2006, The missional leader, Jossey-Bass, San Francisco, CA.

Snyder, H.A. \& Runyon, D.V., 2011, Decoding the church: Mapping the DNA of Christ's body, Wipf and Stock Publishers, Eugene, OR.

Spear, S. \& Bowmen, H.K., 1999, 'Decoding the DNA of the Toyota production system', Harvard Business Review, September-October 1999, pp. 96-106.

Stetzer, E., 2006, Planting missional churches, B\&H Publishing Group, Nashville, TN.

The Archbishops' Council, 2004, Mission-shaped church - Church planting and fresh expressions of church in a changing context, Church House Publishing, London.

Tidball, D., 2008, Ministry by the book - New Testament patterns for pastoral leadership, Apollos - InterVarsity Press, Nottingham, England.

Torrance, J., 1996, Worship, community and the triune God of grace, IVP, Washington. 